Rapp. Grønlands geol. Unders. 69, 5-9 (1975)

\title{
A SEISMIC AND GRAVITY STUDY OF THE WESTERN PART OF THE CRETIACEOUS-TERTIARY SEDIMENTARY BASIN OF CENTRAL WEST GREENLAND
}

\section{J. W. Elder}

\section{Introduction and summary}

In the summer of $1972^{*}$ a GGU seismic group working on land measured the thickness of sediments in the western part of the Nûgssuaq peninsula, West Greenland, by explosion reflection and refraction seismic methods. In the region crudely bounded by Ikorfat, Ubekendt Ejland and Hareøen Cretaceous-Tertiary sediments extend about $1-3 \mathrm{~km}$ below sea level and rest on the granodioritic gneiss basement.

The basin shallows gradually toward the west where it is sharply hidden beneath Tertiary basalts. There is strong evidence for continuity of the Cretaceous-Tertiary sediments across Umanak Fjord as far as Ubekendt Ejland. The most distinctive feature of the basement structure is a ridge, running roughly $\mathrm{N}-\mathrm{S}$ through the western part of the area, and rising about $2 \mathrm{~km}$ above the deeper parts of the basin. This ridge appears as a northerly continuation of the Disko gneiss ridge.

The gravity pattern over a $100 \mathrm{~km} \times 50 \mathrm{~km}$ strip centred on the western part of the basin shows rapid westward thinning of the earth's crust, and suggests that the basin has its origin in an incompletely rifted structure marginal to the crustal rifting responsible for Baffin Bay.

* This outline of the results was originally submitted at the end of 1972 and edited in May 1975. I have, however, chosen not to add anything that has subsequently been determined to the original statement. A detailed, complete report will be published in 1976. 


\section{The seismic work}

\section{Reflection study at Tuperssuartâ}

In this region of terraced ground and river delta surrounded by hills rising to 1-2 km there was only one suitable site for a full spread. This was a T-shaped array placed about $1 \mathrm{~km}$ south of Tuperssuartâ. Charges, typically of a few kilograms, were fired over part of a grid of $200 \mathrm{~m}$ spacing. Charges were buried usually $25-50 \mathrm{~cm}$ and lay on the permafrost. Those placed in the earth of the terraces gave stronger signals and were less hazardous than those in the shingle of the delta.

It was soon apparent that the direct sound wave and echoes from the nearby hills were a dominant feature of the records. Echoing was detectable for about $20 \mathrm{sec}$ from a $1 \mathrm{~kg}$ explosion anywhere in the area. Hence identification of weak ground signals during this echoing phase is difficult. With such shallow explosions and consequent echoes reliable work demands adequate separation of shot and spread. There is however, the nice bonus that the clear character of the direct sound wave allows accurate distance measurements - timings are accurate to much better than 10 millisec and with little air temperature variations distance is known to better than $10 \mathrm{~m}$.

This work showed the presence of surface silt and gravels, a permafrost band, occasional basalt sills to the west, and a pretty uniform sedimentary layer of velocity of order $3.2 \mathrm{~km} / \mathrm{sec}$, resting on basement.

\section{Long range calibration}

A long range calibration shot was fired using a $16 \mathrm{~kg}$ charge at Tuperssuartâ and a portable seismic system was placed at Qeqertalik on Ubekendt Ejland, a range of $25 \mathrm{~km}$. This gave an excellent record both of the ground wave and the wave in the sea water.

This showed that sediments were probably continuous along this profile.

\section{Long range refraction shots along north coast of Nûgssuaq}

Some long range shots were made along the coast. It was found that the sediments identifiable on the Precambrian basement to the east were continuous at depth to the west as far as Kanisut. More importantly it showed that the Tuperssuartâ sediments were probably sitting on a gneiss basement.

Most of the work was done by shooting from ship to shore. The entire party travelled by ship to the next selected observation site and off-loaded the observer and his gear which was set up fairly near the coast. The ship then sailed away from shore firing a refraction profile with shots at about $1 \mathrm{~km}$ interval out to 10 $20 \mathrm{~km}$, then at an intermediate distance of typically $4 \mathrm{~km}$ the ship sailed per- 
pendicular to the refraction profile again firing charges at 1 or $2 \mathrm{~km}$ intervals. The data gives a full refraction profile with lateral fill in. Only when a major structural feature is crossed, and this is obvious in the records, does the fill-in data become unreliable. The only problem with this method is navigation but fortunately the water wave pulse gives distances accurate to much better than $0.1 \mathrm{~km}$.

\section{Seismic results}

The major results are summarised in fig. 1 . The key interface is the base of the $3.2 \mathrm{~km} / \mathrm{sec}$ sediments shown relative to sea level. Note that the contours shown inland are hypothetical - only where they cross the coast have they been determined.

The northern section appears to straddle a single basin, deepening to about 2.8 $\mathrm{km}$ east of Niaqornat. Both the western and eastern margins of the basin are fairly well defined: there is a distinct change in the character of the records in the Sangmissoq area, where to the west we enter the province of the upper basalt formation, and at Ikorfat on the east of the basin gneissic basement is exposed at and above sea level.

The southern section is open to the east where it was not explored during 1972. Nevertheless a basin of depth about $2.6 \mathrm{~km}$ is clearly identified to the east. A

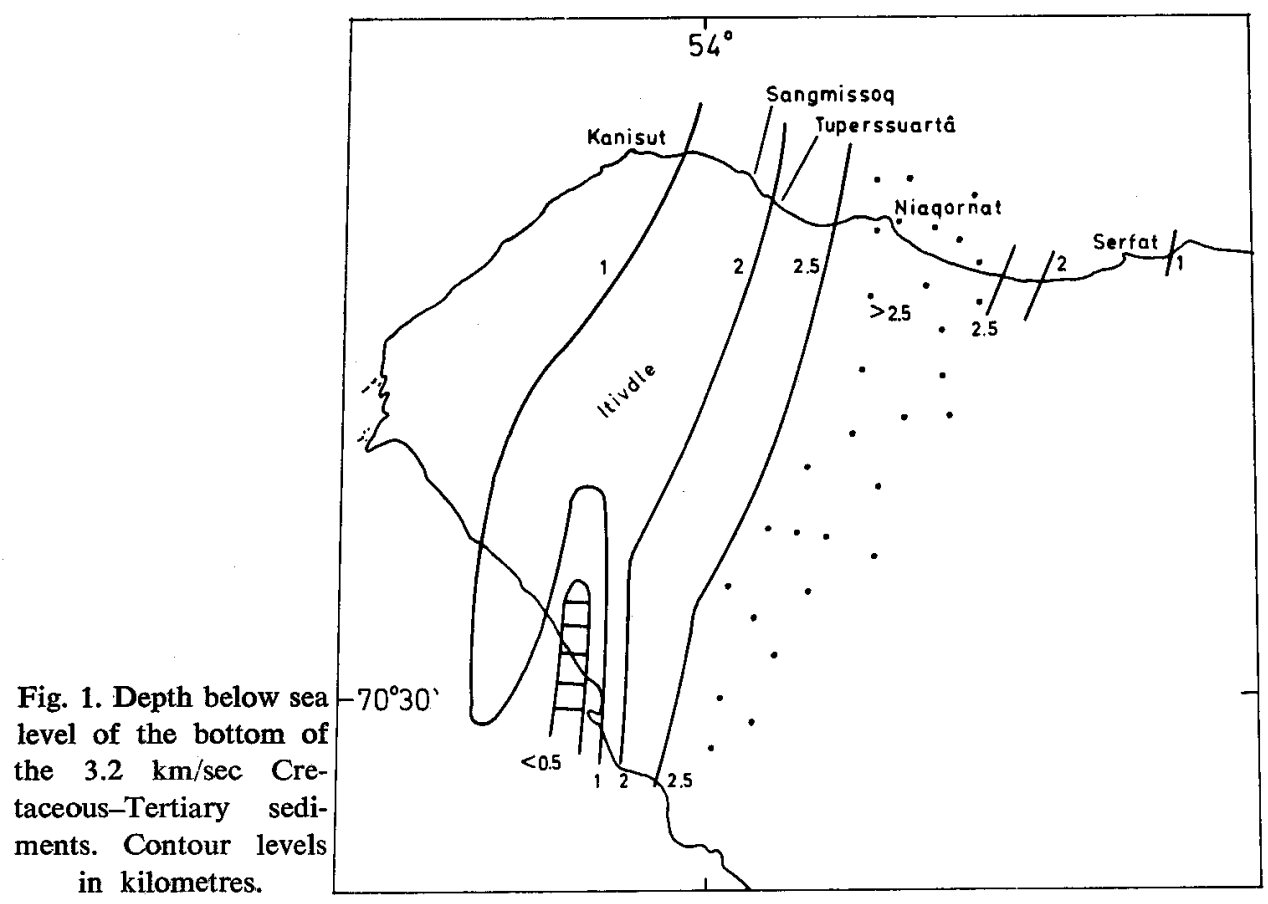




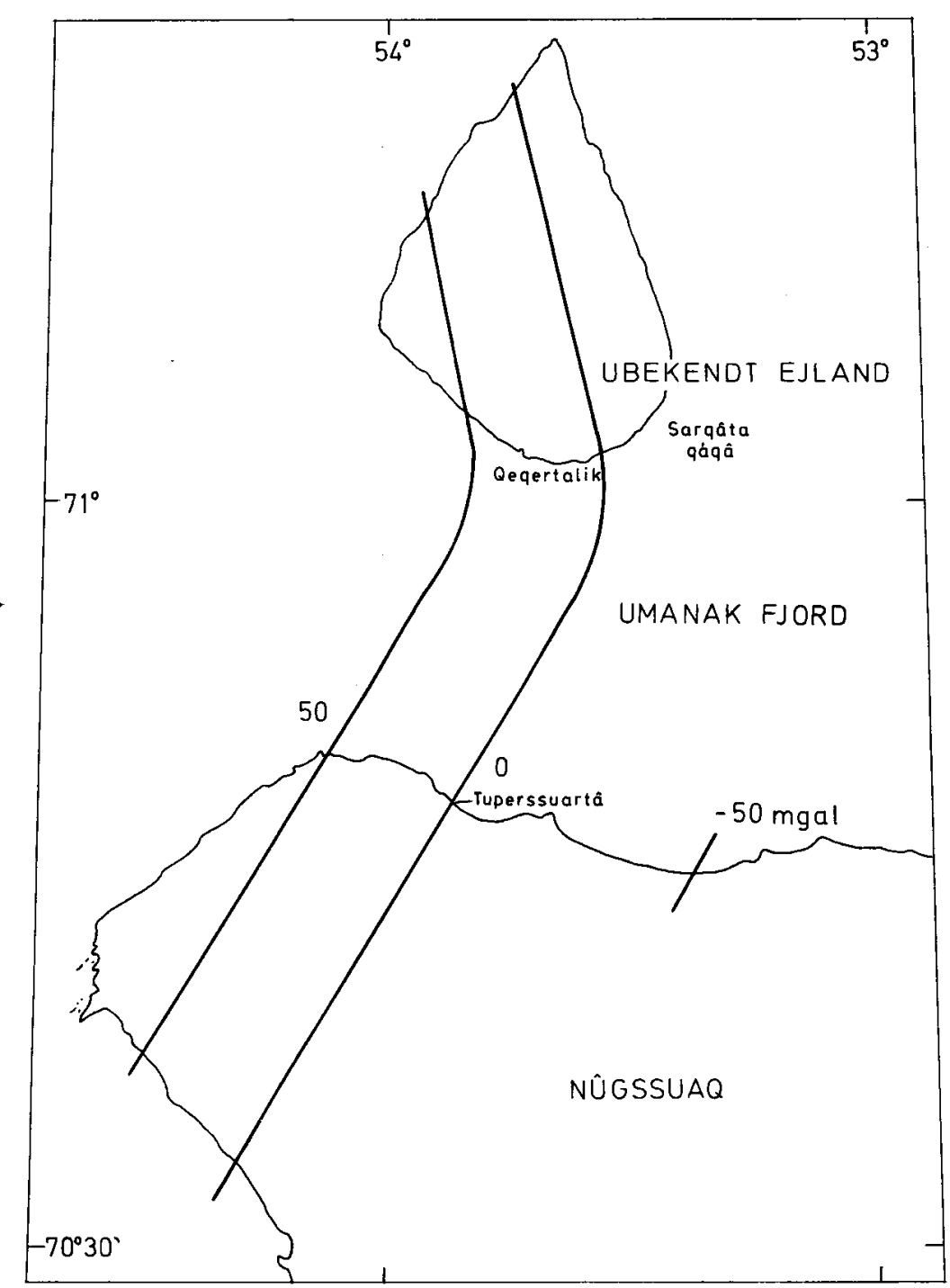

Fig. 2. Gravity anomaly in milligals at sea level relative to Tuperssuartâ base.

further minor basin is found in the Itivdle region. Again the western margin of this minor basin is revealed by changes in the record pattern. Between these two basins is a pronounced basement ridge of elevation $2 \mathrm{~km}$ above the eastern basin and lateral extent $\mathrm{E}-\mathrm{W}$ of order $10 \mathrm{~km}$.

The ridge is the major surprise of this work. The temptation is overwhelming to identify it with a northward extension of the Disko gneiss ridge, which runs from 
Kronprinsens Ejland through Godhavn and outcrops as far north as Stordal in north Disko.

On the broad scale the really striking feature of the results is that the overall strike of the basement structure parallels the gravity contours (fig. 2). This is especially clear for the deeper contours on the west of the basin - notably as shown in fig. 1 those at 2 and $2.5 \mathrm{~km}$. In particular we note that this strike cuts across the Itivdle valley, which therefore must have its control in the upper crust and is not a consequence of deep crustal processes.

\section{Gravity results}

Gravity measurements were made with a La Coste gravimeter at the storm line on beaches on north and south Nûgssuaq and around Ubekendt Ejland. Readings were generally taken to the nearest 0.05 milligal. The data uncorrected for topography is shown in fig. 2.

The pronounced westerly increase across the area indicates a rapid crustal thinning. This thinning wedges into the area on a line passing SSE under the southern end of Ubekendt Ejland. It is interesting to note that the only central complex in the entire basaltic province is on this wedging line at Sarqâta qáqâ. 